19 (4): 387 - 394 (2020)

๑ ( / ISSN 07177917 / www.blacpma.ms-editions.cl

\title{
Articulo Original / Original Article \\ Repellent activity of the essential oil from Laurelia sempervirens (Ruiz \& Pav.) Tul. (Monimiaceae) on Triatoma infestans (Klug) (Reduviidae)
}

\author{
[Actividad repelente del aceite esencial de Laurelia sempervirens (Ruiz \& Pav.) Tul. (Monimiaceae) \\ en Triatoma infestans (Klug)(Reduviidae)]
}

\section{Marycruz Mojica $^{1}$, Raúl Adolfo Alzogaray ${ }^{2}$, Sofía Laura Mengoni ${ }^{2}$, Mercedes María Noel Reynoso ${ }^{2}$, Carlos Fernando Pinto ${ }^{1}$, Hermann M. Niemeyer ${ }^{3}$ \& Javier Echeverría ${ }^{4}$}

\author{
${ }^{1}$ Facultad de Ciencias Químico Farmacéuticas y Bioquímicas de la Universidad Mayor Real y Pontificia de San Francisco Xavier de \\ Chuquisaca, Sucre, Bolivia \\ ${ }^{2}$ Centro de Investigaciones de Plagas e Insecticidas (UNIDEF-CITEDEF-CONICET-CIPEIN). Villa Martelli, Buenos Aires, Argentina \\ ${ }^{3}$ Departamento de Química, Facultad de Ciencias, Universidad de Chile, Santiago, Chile \\ ${ }^{4}$ Departamento de Ciencias del Ambiente, Facultad de Química y Biología Universidad Santiago de Chile \\ Contactos | Contacts: Javier ECHEVERRÍA - E-mail address: javier.echeverriam@usach.cl
}

\begin{abstract}
Triatoma infestans (Klug) is the principal vector of Chagas disease in Bolivia and neighboring countries. The objective of this study was to determine the chemical composition of the EO of the Chilean laurel, Laurelia sempervirens (Ruiz \& Pav.) Tul. (Monimiaceae) and to evaluate its repellent effect on fifth-instar nymphs of T. infestans. The EO from L. sempervirens was obtained by hydrodistillation and analyzed by gas chromatography coupled to mass spectrometry (GC-MS). Their main components were cis-isosafrole (89.8\%), $\beta$ terpinene (3.9\%), trans-ocimene $(2.7 \%)$ and methyleugenol $(2.2 \%)$. Repellency was evaluated on a circle of filter paper divided into two equal zones which were impregnated with test substances [EO or $N, N$-diethyl-3-methylbenzamide (DEET) as positive control] and acetone as blank control, respectively. Several concentrations of test substances between 4.125 and $132 \mu \mathrm{g} / \mathrm{cm}^{2}$ were tested. The EO from $L$. sempervirens produced significant repellency at concentrations equal or above $66.0 \mu \mathrm{g} / \mathrm{cm}^{2}$, while DEET repelled starting at $16.5 \mu \mathrm{g} / \mathrm{cm}^{2}$. Future works will be oriented to the study of repellent properties of cis-isosafrole alone and mixed with $\beta$-terpinene, trans-ocimene and methyleugenol on T. infestans.
\end{abstract}

Keywords: Triatoma infestans; Laurelia sempervirens; Essential oils; Cis-isosafrole; Repellent activity.

Resumen: Triatoma infestans (Klug) es el vector principal de la enfermedad de Chagas en Bolivia y los países vecinos. El objetivo de este estudio fue determinar la composición química del AE del laurel chileno, Laurelia sempervirens (Ruiz \& Pav.) Tul. (Monimiaceae) y evaluar su efecto repelente en ninfas del quinto estadio de T. infestans. La AE de L. sempervirens se obtuvo por hidrodestilación y se analizó por cromatografía de gases acoplada a espectrometría de masas (CG-EM). Sus componentes principales fueron cis-isosafrol (89.8\%), $\beta$ terpineno (3.9\%), trans-ocimeno (2.7\%) y metileugenol (2.2\%). La repelencia se evaluó en un círculo de papel de filtro dividido en dos zonas iguales que se impregnaron con sustancias de prueba [AE o $N, N$-dietil-3-metilbenzamida (DEET) como control positivo] y acetona como control en blanco, respectivamente. Se analizaron varias concentraciones de sustancias de prueba entre 4.125 y $132 \mu \mathrm{g} / \mathrm{cm}^{2}$. El AE de L. sempervirens produjo una repelencia significativa a concentraciones iguales o superiores a $66.0 \mu \mathrm{g} / \mathrm{cm}^{2}$, mientras que DEET repelió a partir de $16.5 \mu \mathrm{g} / \mathrm{cm}^{2}$. Futuros trabajos serán orientados al estudio de las propiedades repelentes de cis-isosafrol solo y mezclado con $\beta$ terpineno, trans-ocimeno y metileugenol en $T$. infestans.

Palabras clave: Triatoma infestans; Laurelia sempervirens; Aceites esenciales; Cis-isosafrole; Actividad repelente

Este artículo puede ser citado como / This article must be cited as: M Mojica, RA Alzogaray, SL Mengoni, MMN Reynoso, CF Pinto, HM Niemeyer, J Echeverría. 2020. Repellent activity of the essential oil from Laurelia sempervirens (Ruiz \& Pav.) Tul. (Monimiaceae) on Triatoma infestans (Klug). Bol Latinoam Caribe Plant Med Aromat 19 (4): 387 - 394. https://doi.org/10.37360/blacpma.20.19.4.26 


\section{INTRODUCTION}

Chagas disease, also called American trypanosomiasis, is caused by the protozoan Trypanosoma cruzi (Pérez-Molina, 2018). It is transmitted as disease by blood-sucking bugs belonging to the family Reduviidae. The main vector of Chagas in Bolivia is Triatoma infestans (Hemiptera: Reduviidae) (Torrico, 2007; RojasCortez, 2007). According to WHO (2015), vector control is considered the most advantageous method for preventing Chagas disease in Latin America. At present, most campaigns of Chagas vector control are based on spraying pyrethroid formulations diluted in water (Vassena et al., 2007). In Bolivia, the National Chagas Program performs controls inside and outside homes to eliminate transmission of the vector (RojasCortez, 2007). Most Bolivian domestic populations of $T$. infestans are resistant to the pyrethroid deltamethrin (Vassena et al., 2007; Lardeux et al., 2010). On the other hand, it is desirable to replace conventional insecticides with alternatives having less environmental impact and less toxicity towards non-pest organisms (Diaz-Barriga, 2002). For these reasons, there is a constant search for new tools to control triatomines as well as for the design of integrated pest management strategies (Lardeux et al., 2010).

Essential oils (EOs) are complex mixtures of monoterpenes and other substances (Isman, 2008) which display a broad spectrum of insecticidal activity (Park et al., 2003; Sfara et al., 2009; Tarelli et al., 2009; Alzogaray et al., 2011; Urzúa et al., 2010; Urzúa et al., 2011a; Urzúa et al., 2011b; Urzúa et al., 2013; Echeverría \& Albuquerque, 2019). Lethal as well as sublethal repellency effects of terpenes on insects have been extensively documented (Katz et al., 2008; Sfara et al., 2009; Moretti, 2017).

Laurelia sempervirens (Ruiz \& Pav.) Tul. (Monimiaceae) is an evergreen endemic tree of the temperate rainforests of southern Chile, mainly on the coast between the Región del Libertador General Bernardo O'Higgins and Región de los Lagos (Rodríguez et al., 2018). Different extracts from the plant have shown a variety of activities against insects. Thus, the EO from leaves and bark of $L$. sempervirens showed insecticidal and repellent activity towards the confused flour beetle Tribolium confusum (Zapata \& Smagghe, 2010; Torres et al., 2014; Herrera-Rodríguez et al., 2015; Torres et al., 2015; Ortiz et al., 2017), the greenhouse white fly Trialeurodes vaporariorum and its chalcidoid parasitic wasp Encarsia formosa (Zapata et al., 2016), and the pea aphid Acyrthosiphon pisum (Zapata et al., 2010), while the leaf powder produced lethal and sublethal effects on the maize weevil Sitophilus zeamais (Torres et al., 2015; Noranbuena et al., 2016) and the bean weevil Acanthoscelides obtectus (Bittner et al., 2008). The aim of this study was to determine the chemical composition of the EO from leaves of $L$. sempervirens and its repellent effect towards fifth-instar nymphs of $T$. infestans.

\section{MATERIAL AND METHODS Chemicals}

$N, N$-diethyl-3-methylbenzamide DEET (97\%) and acetone (analytical grade) were purchased to Sigma Aldrich (Buenos Aires, Argentina) and Merck (Darmstadt, Germany), respectively.

\section{Biological material}

The assays were performed with fifth-instar nymphs of Triatoma infestans (colony CIPEIN). This colony was maintained at $26 \pm 2{ }^{\circ} \mathrm{C}$ and $60-90 \%$ relative humidity (RH); and weekly fed pigeon blood, according to the protocol approved by the Institutional Animal Care and Use Committee of CIPEIN (IACUC/CICUAL - National System of Bioterium Registry Number 1572/155).

\section{Extraction and chemical analysis of the EO from $L$. sempervirens \\ Plant material}

Leaves from adult trees of $L$. sempervirens (Ruiz et Pav.) Tul. were collected near Valdivia, Chile (39 52.395S, $73^{\circ} 14.5970,4$ m.a.s.1.). Following Vogel et al. (1997), care was taken to haphazardly collect leaves from different positions of each of several trees. The material was identified by Sebastián Teillier, Universidad Central de Chile. Voucher specimens (LQE-231) were deposited at the herbarium of the Laboratorio de Química Ecológica, Facultad de Ciencias, Universidad de Chile.

\section{Essential oil extraction}

Plant material (ca. $30 \mathrm{~g}$ ) was air dried, cut into small pieces, and hydrodistilled for $3 \mathrm{~h}$ in a Clevenger-type apparatus (Echeverría \& Niemeyer, 2017). The yellowish oil was dried over anhydrous sodium sulphate and stored in a glass ampoule at $4{ }^{\circ} \mathrm{C}$ until 
analysed.

\section{Chromatographic analysis}

A Hewlett-Packard 5891 gas chromatograph linked to a Hewlett-Packard 5972 mass spectrometric detector (Hewlett Packard, Palo Alto, CA, USA) and provided with a capillary column (SPB-5, 30m x 0.25 $\mathrm{mm}$, film thickness $0.25 \mu \mathrm{m}$, Supelco, Deerfield IL, USA).Operating conditions were as follows: oncolumn injection; injector and detector temperatures, $150^{\circ} \mathrm{C}$ and $280^{\circ} \mathrm{C}$, respectively. The carrier gas was $\mathrm{He}$ at a flow of $1.3 \mathrm{~mL} / \mathrm{min}$. The oven temperature was programmed as follows: $50{ }^{\circ} \mathrm{C}$ for $10 \mathrm{~min}$, increase to $280{ }^{\circ} \mathrm{C}$ at $5^{\circ} \mathrm{C} / \mathrm{min}$, and then $280^{\circ} \mathrm{C}$ for $45 \mathrm{~min}$. In the mass detector, ionization was by electron impact at $70 \mathrm{eV}$; scan time, $1.5 \mathrm{~s}$; and acquisition mass range, 50 to 500 Dalton. Compounds were identified by: i) calculation and comparison of retention indexes (Kovats indexes, KI) with those reported in the literature (Adams, 2012) or with those of available chemicals; and ii) comparison of mass spectra with those in the NIST98 library database. The integrated data system provided relative peak areas which were used as semiquantitative composition data.

\section{Bioassays}

Experiments were carried out in a melamine-coated wooden box $(1.0 \times 0.5 \times 0.5 \mathrm{~m}$, length $\mathrm{x}$ width $\mathrm{x}$ height). The experimental arena was a filter paper disc (110 $\mathrm{mm}$ in diameter) (Hangzhou Xinxing Paper Industry \& Co. Ltd.) placed centrally on the floor of the box. A video camera was located $20 \mathrm{~cm}$ above the arena (HD Webcam C525, Logitech, Lausanne, Switzerland) and connected to a personal computer. The camera has a resolution of $640 \times 480$ pixels with an acquisition and image processing speed of 30 frames/second. Lighting was provided by a bulb (22 watts; Luxa, Shanghai, China) placed above the paper circle. Temperature and relative humidity were $25^{\circ} \mathrm{C}$ and $80 \%$, respectively.

The circle of filter paper was cut into halves. One half was treated with $0.25 \mathrm{~mL}$ of an acetonic solution of DEET or EO, and the other half with 0.25 $\mathrm{mL}$ of acetone alone. DEET was used as positive control and also to compare the effect of the EO with that of a regularly used insecticide; acetone was used as blank (Sfara et al., 2011). The following concentrations were applied: $4.125,8.25,16.5,33$, and $66 \mu \mathrm{g} / \mathrm{cm}^{2}$ of DEET; and 8.25, 16.5, 33, 66 and $132 \mu \mathrm{g} / \mathrm{cm}^{2}$ of EO. After the solvent had evaporated, both halves were stuck back together with adhesive tape on the underside, and the circle was placed on the horizontal floor of the test box. Then, a glass cylinder $(2.5-\mathrm{cm}$ high, $10-\mathrm{cm}$ diameter) was placed around the paper circle to prevent the nymphs from leaving the arena. Finally, a nymph was gently deposited at the center of the arena. The time spent by the nymph on each half of the experimental arena was recorded for ten minutes. The position of the nymph in one or the other half of the paper were determined from playbacks of the recordings. The center of gravity of the insect was used to determine its position. Six independent replicates were performed.

Results were expressed as a Distribution coefficient $(\mathrm{DC}=(\mathrm{AT}-\mathrm{At}) / \mathrm{AT}$; where $\mathrm{AT}$ is the total time of the experiment, and At is the time of the nymph spent in the treated half). DC varies from 0 to 1,0 being the maximum value of attraction and 1 the maximum value of repellency. A value of 0.5 indicates that there is an equal distribution between the treated and untreated areas (Sfara et al., 2011). The results were analyzed using one-way ANOVA followed by Tukey's test.

\section{RESULTS}

Table No. 1 shows the chemical composition of the EO from $L$. sempervirens. The 11 compounds identified accounted for $99.88 \%$ of the total peak area. The main component was cis-isosafrole $(89.8 \%)$, followed by $\beta$-terpinene $(3.9 \%)$, transocimene $(2.7 \%)$ and methyleugenol $(2.2 \%)$. Other components were present at relative areas less than $0.7 \%$.

DEET showed a significant, concentrationdependent repellent activity on fifth-instar nymphs of T. infestans (ANOVA, $\mathrm{F}=5.811, \mathrm{DF}=5,16, p=0.003$ ) (Figure No. 1). The minimum concentration of DEET that produced repellency was $16.5 \mu \mathrm{g} / \mathrm{cm}^{2}$ (DC=0.82). The EO from $L$. sempervirens also modified significantly the behaviour of the nymphs (ANOVA, F=8.824, DF=5, 18, $p<0.001$ ) (Figure No. $2)$. The repellent effect also depended on the concentration and could be observed at concentrations $66.0 \mu \mathrm{g} / \mathrm{cm}^{2}(\mathrm{DC}=0.91)$ and above.

\section{DISCUSSION}

In this work, the EO from leaves of the Chilean laurel, L. sempervirens, showed repellent activity towards fifth-instar nymphs of $T$. infestans. The minimum concentration that produced significant 
repellency was four times higher than the minimum concentration required of the positive control (DEET).

Several studies have reported safrole as the major component in the EO from leaves of $L$. sempervirens (Montes et al., 1990; Bittner et al., 2008; Bittner et al., 2009; Zapata et al., 2010; Herrera-Rodriguez et al., 2015). Here we found a very different composition, where cis-isosafrole $(89.8 \%)$ and, to a much lesser extent, $\beta$-terpinene (3.9\%), trans-ocimene $(2.7 \%)$ and methyleugenol (2.2\%) were the main components. Recently, Zapata et al. (2016) reported $\alpha$-isosafrole and $\beta$-isosafrole $(33.86 \%)$ in the EO of $L$. sempervirens, thus more closely resembling our results.

Table No. 1

Chemical composition of the essential oil of leaves of $L$. sempervirens

\begin{tabular}{clccc}
\hline Peak & \multicolumn{1}{c}{ Compound $^{\mathbf{a}}$} & RI calc. & $\begin{array}{c}\text { Relative area } \\
(\boldsymbol{\%})^{\mathbf{c}}\end{array}$ & $\begin{array}{c}\text { Methods of } \\
\text { identification }^{\mathbf{d}}\end{array}$ \\
\hline 1 & $\alpha$-pinene & 939 & 0.70 & MS,RI,ST \\
2 & $\beta$-pinene & 980 & 0.10 & MS,RI,ST \\
3 & $\alpha$-phellandrene & 1006 & 0.20 & MS,RI,ST \\
4 & $\beta$-terpinene & 1035 & 3.90 & MS,RI,ST \\
5 & trans-ocimene & 1054 & 2.70 & MS,RI \\
6 & linalool & 1101 & 0.03 & MS,RI,ST \\
7 & $\alpha$-terpineol & 1196 & 0.05 & MS,RI \\
8 & cis-isosafrole & 1310 & 89.8 & MS,RI,ST \\
9 & methyleugenol & 1411 & 2.20 & MS,RI,ST \\
10 & $\beta$-caryophyllene & 1438 & 0.10 & MS,RI \\
11 & germacrene B & 1496 & 0.10 & \\
\hline & Total Identified & & 99.88 & \\
\hline & Hydrocarbon monoterpenes & & 7.60 & 0.08 \\
\\
& Oxygenated monoterpenes & & 0.20 & \\
& Hydrocarbon sesquiterpenes & & 92.0 & \\
\hline
\end{tabular}

${ }^{\text {a}}$ Compounds listed in order of elution in SPB-5 column; ${ }^{b}$ Retention indexes calculated (RI $\mathrm{Ralc}_{\text {casing }}$ u homologous series of $\boldsymbol{n}$-alkanes $\mathrm{C}_{7}-\mathrm{C}_{40}$ in SPB-5 column; ${ }^{\mathrm{C} P e a k}$ areas relative to total peak area; ${ }^{\mathrm{d} B a s e s}$ for dentification: comparison of mass spectra using the NIST98 MS library and the literature (MS), retention index (RI) and/or authentic compounds (ST).

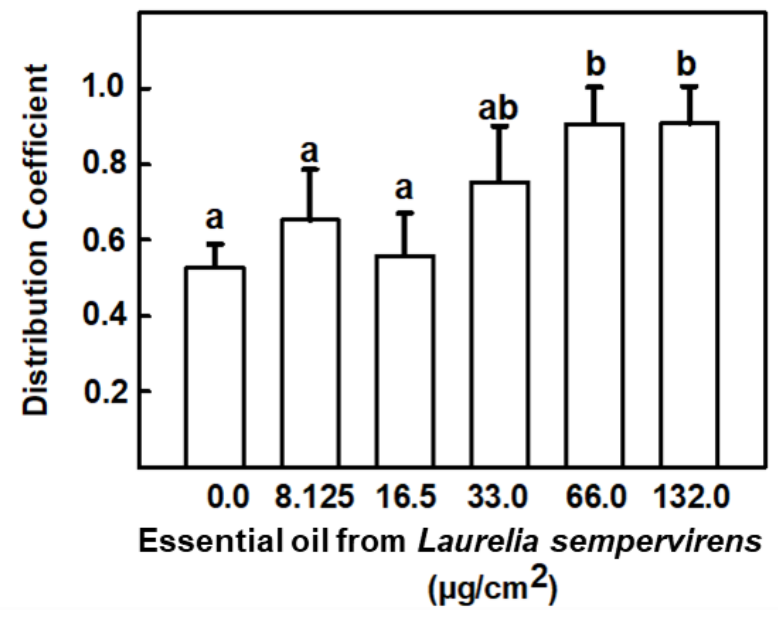

Figure No. 1

Repellent effect of essential oil from Laurelia sempervirens leaves on fifth-instar nymphs of $T$. infestans. Each bar is the mean of six independent replicates. Vertical lines are SE. Distribution coefficient (DC) $=(\mathrm{AT}$-At $) / \mathrm{AT}$; where AT is the total time of the experiment, and At is the time of the nymph spent the treated half). Bars marked with different letters are significantly different $(\boldsymbol{p}<\mathbf{0 . 0 5})$. 


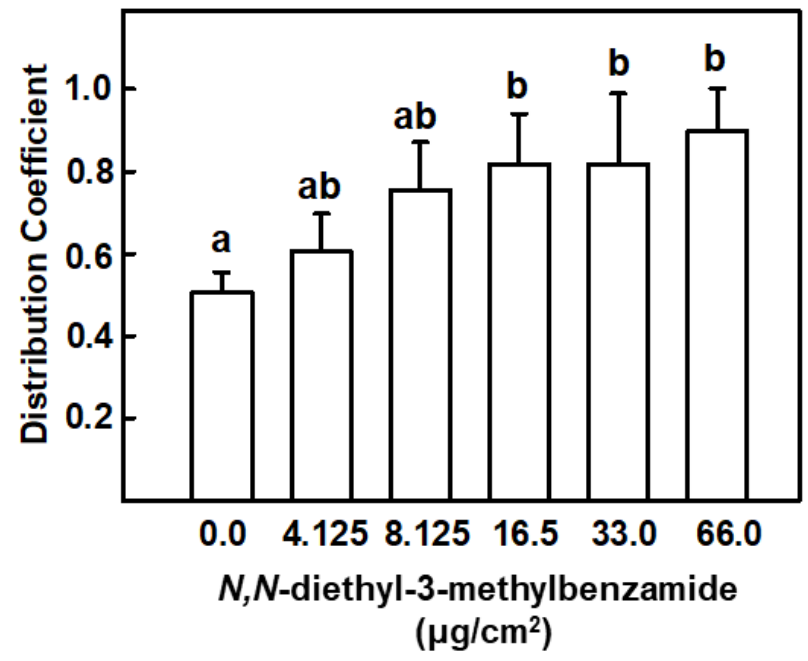

Figure No. 2

Repellent effect of $N, N$-diethyl-3-methylbenzamide (DEET) on fifth-instar nymphs of Triatoma infestans. Each bar is the mean of six independent replicates. Vertical lines are SE. Distribution coefficient $(\mathrm{DC})=(\mathrm{AT}$-At $) / \mathrm{AT}$; where AT is the total time of the experiment, and At is the time of the nymph spent the treated half). Bars marked with different letters are significantly different $(p<0.05)$.

The differences in the chemical composition of the EO of $L$. sempervirens may be due to the collection time and also to exogenous factors such as light, precipitation, growing site, soil quality. Seasonal variation and the occurrence of ecotypes and chemotypes may also be expected. Endogenous factors such as age, plant part processed, as well as the extraction techniques can also be responsible for the variations observed (Barra, 2009). Particularly, the seasonal variation of the insecticidal and insectistatic properties of the essential oil of $L$. sempervirens in the control of $S$. zeamais has been demonstrated (Ortiz et al., 2017).

In our study, the major component in the EO from L. sempervirens was isosafrole (89.8\%), a benzenoid that was previously reported with insecticidal and repellent activities against other insects such as the American cockroach, Periplaneta americana (Ngoh et al., 1998). On the other hand, safrole and its isomerized regioisomer, isosafrole, have been identified as natural pesticides towards the beetles S. zeamais (Coleoptera: Curculionidae) and Tribolium castaneum (Herbst) (Coleoptera: Tenebrionidae) (Huang et al., 1999). In addition, isosafrole has shown a potent synergistic activity with pyrethroid insecticides towards adult house flies Musca domestica (Scott, 1996). Furthermore, methyleugenol has shown important insecticidal properties against various insects (Huang et al., 2002;
$\mathrm{Xu}$ et al., 2015). The high concentration of these compounds suggest their leading role in the repellent effect of the L. sempervirens EO.

The repellent activity of the EO of $L$. sempervirens was of the same order of magnitude as that of DEET, a universal repellent of insects whose effect is rarely surpassed by other substances (Zhu et al., 2018). This result should make it worthwhile to study the repellent properties of cis-isosafrole alone and mixed with $\beta$-terpinene, trans-ocimene and methyleugenol on $T$. infestans and other pest insects.

\section{CONCLUSION}

The EO from $L$. sempervirens leaves produced an important repellent effect on fifth-instar nymphs of $T$. infestans under laboratory conditions. Testing it under natural conditions would be desirable. The effect was of the same order of magnitude as that of DEET, suggesting the study of the repellent action of cis-isosafrole, the main component of the EO from $L$. sempervirens leaves, alone or mixed with other compounds.

\section{ACKNOWLEDGMENTS}

$\mathrm{MM}$ is indebted to Centro de Investigaciones de Plagas e Insecticidas (UNIDEF-CITEDEFCONICET-CIPEIN), Argentina, for providing training and guidance in the bioassays. CFP and MM are indebted to $\mathrm{BOL}-01$ project of the International 
Science Programme at Uppsala University for the funding support for this project.Support from the BOL-01 program of the International Science
Program at Uppsala University. JE grateful the funding provided by project CONICYT PAI/ACADEMIA 79160109.

\section{REFERENCES}

Adams RP. 2007. Identification of essential oil components by gas chromatography/mass spectrometry. Carol Stream, Illinois, USA.

Alzogaray RA, Lucia A, Zerba E, Masuh H. 2011. Insecticidal activity of essential oils from eleven Eucalyptus spp. and two hybrids: lethal and sublethal effects of their major components on Blattella germanica. J Econ Entomol 104: 595 - 660. https://doi.org/10.1603/ec10045

Barra A. 2009. Factors affecting chemical variability of essential oils: a review of recent developments. Nat Prod Commun 4: 1147-1154.

Bittner ML, Casanueva ME, Arbert CC, Aguilera MA, Hernández VJ, Becerra JV. 2008. Effects of essential oils from five plant species against the granary weevils Sitophilus zeamais and Acanthoscelides obtectus (Coleoptera).J Chil Chem Soc 53: 1455 - 1459. https://doi.org/10.4067/s0717-97072008000100026

Bittner M, Aguilera M, Hernández V, Arbert C, Becerra J, Casanueva, M. 2009. Fungistatic activity of essential oils extracted from Peumus boldus Mol., Laureliopsis philippiana (Looser) Schodde and Laurelia sempervirens (Ruiz \& Pav.) Tul. (Chilean Monimiaceae).Chil J Agric Res 69: 29 - 37. https://doi.org/10.4067/s0718-58392009000100004

Díaz-Barriga F. 2002. Factores de Exposición y Toxicidad del DDT y de la Deltametrina en Humanos y en Vida Silvestre. Informe Técnico Apoyado por la Comisión de Cooperación Ambiental de América del Norte. Universidad Autónoma de San Luis Potosí, Bolivia.

Echeverría J, Albuquerque RDDGD. 2019. Nanoemulsions of essential oils: New tool for control of vector-Borne diseases and in vitro effects on some parasitic agents. Medicines 6: 42. https://doi.org/10.3390/medicines6020042

Echeverría J, Niemeyer HM. 2017. Essential oil of Kurzamra pulchella (Clos) Kuntze (Lamiaceae, Nepetoideae, Mentheae, Menthinae): relationship with chemotype groups in the subtribe Menthinae. Nat Prod Res 31: 108 - 112. https://doi.org/10.1080/14786419.2016.1214828

Herrera-Rodríguez C, Ramírez-Mendoza C, Becerra-Morales I, Silva-Aguayo G, Urbina-Parra A, Figueroa-Cares I, Martínez-Bolaños L, Rodríguez JC, Lagunes-Tejeda A, Pastene-Navarrete E, Bustamante-Salazar, L. (2015). Bioactivity of Peumus boldus Molina, Laurelia sempervirens (Ruiz \& Pav.) Tul. and Laureliopsis philippiana (Looser) Schodde (Monimiacea) essential oils against Sitophilus zeamais Motschulsky. Chil J Agric Res 75: 334 - 340. https://doi.org/10.4067/s0718-58392015000400010

Huang Y, Ho SH, Kini RM. 1999. Bioactivities of Safrole and Isosafrole on Sitophilus zeamais (Coleoptera: Curculionidae) and Tribolium castaneum (Coleoptera: Tenebrionidae). J Econ Entomol 92: 676 - 683. https://doi.org/10.1093/jee/92.3.676

Huang Y, Ho SH, Lee HC, Yap YL. 2002. Insecticidal properties of eugenol, isoeugenol and methyleugenol and their effects on nutrition of Sitophilus zeamais Motsch. (Coleoptera: Curculionidae) and Tribolium castaneum (Herbst)(Coleoptera: Tenebrionidae). J Stored Prod Res 38: 403 - 412.

https://doi.org/10.1016/s0022-474x(01)00042-x

Isman M. 2008. Botanical insecticides: for richer, for poorer. Pest Manag Sci 64: 8 - 11. https://doi.org/10.1002/ps.1470

Katz TM, Miller JH, Hebert AA. 2008. Insect repellents: historical perspectives and new developments. J Am Acad Dermatol 58: 865 - 871. https://doi.org/10.1016/j.jaad.2007.10.005

Lardeux F, Depickére S, Duchon S, Chávez T. 2010. Insecticide resistance of Triatoma infestans (Hemiptera, Reduviidae) vector of Chagas diasease in Bolivia. Trop Med Int Health15: 1037 - 1048. https://doi.org/10.1111/j.1365-3156.2010.02573.x

Montes M, Valenzuela L, Wilkomirsky T. 1990. Safrol: principal componente del aceite esencial de Laurelia sempervirens (R. y P.) Tul. desde el área de Bio-Bio (Chile). An Real Acad Farm 56: 49 - 54.

Moretti A, Seccacini A, Zerba E, Canale D, Alzogaray R. 2017 The botanical monoterpenes linalool and eugenol flush-out nymphs of Triatoma infestans (Hemiptera: Reduviidae). J Med Entomol 54: 1293 - 1298. https://doi.org/10.1093/jme/tjx068 
Ngoh SP, Choo LE, Pang FY, Huang Y, Kini MR, Ho SH. 1998. Insecticidal and repellent properties of nine volatile constituents of essential oils against the American cockroach, Periplaneta americana (L.). Pestic Sci 54: 261 - 268. https://doi.org/10.1002/(sici)1096-9063(1998110)54:3<261::aid-ps794>3.0.co;2-c

Norambuena C, Silva G, Urbina A, Figueroa I, Rodríguez JC. 2016. Insecticidal activity of Laureliopsis philippiana (Looser) schodde (Atherospermataceae) essential oil against Sitophilus spp. (Coleoptera, Curculionidae). Chil J Agric Res 76: 330 - 336. https://doi.org/10.4067/s0718-58392016000300010

Ortiz C, Silva G, Moya E, Fischer S, Urbina A, Rodriguez C. 2017. Seasonal variation of repellency of essential oils of Monimiaceae against Sitophilus zeamais Motschulsky (Curculionidae). Chil J Agric Anim Sci 33: 221 - 230. https://doi.org/10.4067/s0719-38902017005000604

Park I, Lee S, Cho D, Park J, Ahn Y. 2003. Insecticidal activities of constituents identified in the essential oil from leaves of Chamaecyparis obtusa against Callosobruchus chinensis (L.) and Sitophilus oryzae (L.). J Stored Prod Res 39: 375 - 384. https://doi.org/10.1016/s0022-474x(02)00030-9

Pérez-Molina JA, Molina I. 2018. Chagas disease. The Lancet 391: 82 - 94. https://doi.org/10.1016/s0140-6736(17)31612-4

Rodriguez R, Marticorena C, Alarcón D, Baeza C, Cavieres L, Finot VL, Kiessling A, Mihoc M, Pauchard A, Ruiz E, Sánchez P, Ruiz E. 2018. Catálogo de las plantas vasculares de Chile. Gayana Bot 75: 1 - 430. https://doi.org/10.4067/s0717-66432018000100001

Rojas-Cortez M. 2007. Triatominos de Bolivia y la enfermedad de Chagas. Ministerio de Salud y Deportes, Programa Nacional de Chagas, Bolivia.

Scott JG. 1996. Inhibitors of CYP6D1 in house fly microsomes. Insect Biochem Mol Biol 26: 645 - 649. https://doi.org/10.1016/s0965-1748(96)00008-2

Sfara V, Zerba E, Alzogaray R. 2009. Fumigant insecticidal activity and repellent effect of five essential oils and seven monoterpenes on first-instar nymphs of Rhodnius prolixus. J Med Entomol 46: 511 - 515. https://doi.org/10.1603/033.046.0315

Sfara V, Mougabure-Cueto G, Zerba EN, Alzogaray RA. 2011. Adaptation of the repellency response to DEET in Rhodnius prolixus. J Insect Physiol, 57: 1431 - 1436. https://doi.org/10.1016/j.jinsphys.2011.07.009

Tarelli G, Zerba EN, Alzogaray RA. 2009. Toxicity to vapor exposure and topical application of essential oils and monoterpenes on Musca domestica (Diptera: Muscidae). J Econ Entomol 102: 1383 - 1388. https://doi.org/10.1603/029.102.0367

Torres C, Silva G, Tapia M, Rodríguez J, Figueroa I, Lagunes A, Santillán C, Robles A, Aguilar S, Ticuch I. 2014. Insecticidal activity of Laurelia sempervirens (Ruiz \& Pav.) Tul. essential oil against Sitophilus zeamais Motschulsky. Chil J Agric Res 74: 421 - 426. https://doi.org/10.4067/s0718-58392014000400007

Torres C, Silva G, Tapia M, Rodríguez JC, Urbina A, Figueroa I, Santillan C, Aguilar S, Robles A, Lagunes A. 2015. Propiedades insecticidas del Laurelia sempervirens polvo a Motschulsky Sitophilus zeamais: control (Coleoptera Curculionidae). Bol Latinoam Caribe Plant Med Aromat 14: 48 - 59.

Torrico F. 2007. La enfermedad del Chagas. En: MR Cortez (ed.). Triatominos de Bolivia y la enfermedad de Chagas. Ministerio de Salud y Deportes, Programa Nacional de Chagas, La Paz, Bolivia.

Urzúa A, Santander R, Echeverría J, Cabezas N, Palacios SM, Rossi Y. 2010. Insecticide properties of the essential oils from Haplopappus foliosus and Bahia ambrosoides against the house fly, Musca domestica L. J Chil Chem Soc 55: 392 - 395. https://doi.org/10.4067/s0717-97072010000300026

Urzúa A, Di Cosmo D, Echeverría J, Santander R, Palacios SM, Rossi Y. 2011a. Insecticidal effect of Schinus latifolius essential oil on the housefly, Musca domestica L. Bol Latinoam Caribe Plant Med Aromat 10: $470-475$.

Urzúa A, Echeverría J, Santander R. 2011b. Comparative chemical composition of the essential oils from Pseudognaphalium robustum, P. heterotrichium and P. cheiranthifolium. J Essent Oil Bear PI 14: 600 604. https://doi.org/10.1080/0972060x.2011.10643977

Urzúa A, Modak B, Santander R, Heit C, Echeverría J. 2013. Insecticidal properties of Heliotropium stenophyllum essential oil on the House fly, Musca domestica L. Bol Latinoam Caribe Plant Med Aromat 12: 196-200.

Vassena C, Picollo M, Santo P, Zerba E. 2007. Desarrollo y manejo de la resistencia a insecticidas piretroides en Triaotoma infestans: Situación en Bolivia. In: Triatominos de Bolivia y la enfermedad de Chagas (ed M Rojas Cortez) Ministerio de Salud y Deportes de Bolivia, Programa Nacional de Chagas, La Paz, Bolivia. 
Vogel H, Razmilic I, Doll U. 1997. Essential oil and alkaloid contents of different populations in boldo (Peumus boldus Mol.). Cienc Investig Agrar 24: 1 - 6. https://doi.org/10.1055/s-2006-960450

WHO [World Health Organization]. 2015. Chagas disease in Latin America: an epidemiological update based on 2010 estimates. Wkly Epidemiol Rec 90: 33 - 44.

Xu HX, Zheng XS, Yang YJ, Tian JC, Lu YH, Tan KH, Heong KL, Lu ZX. 2015. Methyl eugenol bioactivities as a new potential botanical insecticide against major insect pests and their natural enemies on rice (Oryza sativa). Crop Prot 72: 144 - 149. https://doi.org/10.1016/j.cropro.2015.03.017

Zapata N, Lognay G, Smagghe G. 2010. Bioactivity of essential oils from leaves and bark of Laurelia sempervirens and Drimys winteri against Acyrthosiphon pisum. Pest Manag Sci 66: 1324 - 1331. https://doi.org/10.1002/ps.2018

Zapata N, Smagghe G. 2010. Repellency and toxicity of essential oils from the leaves and bark of Laurelia sempervirens and Drimys winteri against Tribolium castaneum. Ind Crops Prod 32: 405 - 410. https://doi.org/10.1016/j.indcrop.2010.06.005

Zapata N, Vargas M, Latorre E, Roudergue X, Ceballos R. 2016. The essential oil of Laurelia sempervirens is toxic to Trialeurodes vaporariorum and Encarsia formosa. Ind Crops Prod 84: 418 - 422. https://doi.org/10.1016/j.indcrop.2016.02.030

Zhu JJ, Cermak SC, Kenar JA, Brewer G, Haynes KF, Boxler D, Baker PD, Wang D, Wang C, Li AY, Xue R, Shen Y, Wang F, Agramonte NM, Bernier UR, de Oliveira Filho JG, Borges LMF, Friesen K, Taylor DB, Shen Y. 2018. Better than DEET repellent compounds derived from coconut oil. Sci Rep 8: 1 - 12.

https://doi.org/10.1038/s41598-018-32373-7 